Poster to be presented at the 2002 Gordon Research Conference - Aqueous Corrosion in New London (NH) July 14-19, 2002

\title{
STRESS CORROSION CRACKING BEHAVIOR OF ALLOY 22 IN MULTI-IONIC AQUEOUS ENVIRONMENTS
}

\author{
Kenneth J. King, John C. Estill and Raúl B. Rebak \\ Lawrence Livermore National Laboratory, Livermore, CA, 94550
}

\begin{abstract}
The US Department of Energy is characterizing a potential repository site for nuclear waste in Yucca Mountain (NV). In its current design, the nuclear waste containers consist of a double metallic layer. The external layer would be made of N06022 or Alloy 22 (Ni-22Cr-13Mo-3W-3Fe). Since over their lifetime, the containers may be exposed to multi-ionic aqueous environments, a potential degradation mode of the outer layer could be environmentally assisted cracking (EAC) or stress corrosion cracking (SCC). In general, Alloy 22 is extremely resistant to SCC, especially in concentrated chloride solutions. Current results obtained through slow strain rate testing (SSRT) shows that Alloy 22 may suffer SCC in simulated concentrated water (SCW) at applied potentials approximately $400 \mathrm{mV}$ more anodic than the corrosion potential $\left(\mathrm{E}_{\mathrm{cor}}\right)$.
\end{abstract}

\section{INTRODUCTION}

If water is present, there are three types of corrosion degradation modes that may occur in the containers. These are: (1) General or uniform corrosion, (2) Localized corrosion and (3) Environmentally assisted cracking (EAC). (Figure 1 outlines what corrosion modes are considered and what can affect these corrosion modes.)

Mill annealed Alloy 22 is highly resistant to SCC in acidic concentrated chloride solutions. ${ }^{1-5}$ Dunn et al. did not find SCC when they tested Alloy 22 in 14 molal $\mathrm{Cl}^{-}\left(\right.$as $\left.\mathrm{MgCl}_{2}\right)$ at $110^{\circ} \mathrm{C}$ and 9.1 molal $\mathrm{LiCl}$ at $95^{\circ} \mathrm{C}$ under controlled potential. ${ }^{1-3}$ They used wedge opening loaded double cantilever beam (DCB) and compact tension (CT) specimens at stress intensities in the range 32 to $47 \mathrm{MPa}^{1 / 2}$ for times as long a 52 weeks. ${ }^{1-3}$ Rebak reported that Alloy 22 U-bend specimens did not suffer SCC when exposed to $45 \% \mathrm{MgCl}_{2}$ at $154^{\circ} \mathrm{C}$ for up to 6 weeks. ${ }^{4}$ Estill et al. performed SSRT at a $1.6 \mathrm{x}$ $10^{-6} \mathrm{~s}^{-1}$ strain rate at the corrosion potential $\left(\mathrm{E}_{\text {cor }}\right)$ in $4 \mathrm{M} \mathrm{NaCl}$ at $98^{\circ} \mathrm{C}$, saturated $\mathrm{CaCl}_{2}(>10 \mathrm{M} \mathrm{Cl})$ at $120^{\circ} \mathrm{C}$ and $1 \% \mathrm{PbCl}_{2}$ at $95^{\circ} \mathrm{C} .^{5}$ None of these specimens showed a loss of ductility or secondary cracking $^{5}$ (Table 1).

Even though Alloy 22 is resistant to SCC in concentrated chloride solutions, it may be susceptible under other severe environmental conditions. ${ }^{6-9}$ Andresen et al. tested the susceptibility of Alloy 22 to EAC at the corrosion potential $\left(\mathrm{E}_{\text {corr }}\right)$ in basic saturated water $(\mathrm{BSW})$ at $110^{\circ} \mathrm{C}$. $^{6} \mathrm{This} \mathrm{BSW}$ multiionic solution is a version of concentrated solutions that might be obtained after evaporative tests of Yucca Mountain ground waters. ${ }^{6}$ Using the reversing DC potential drop technique, Andresen et al. reported a crack grow rate of $5 \times 10^{-13} \mathrm{~m} / \mathrm{s}$ in a $20 \%$ cold-worked specimen loaded to a stress intensity of $30 \mathrm{MPa} \cdot \mathrm{m}^{1 / 2}$. This EAC testing was carried out in air saturated BSW water of $\mathrm{pH} \sim 13$. The testing conditions used by Andresen et al. were highly aggressive and, in spite of that, the measured 
crack growth rate was near the detection limit of the system. ${ }^{6}$ Rebak et al. reported that Alloy $22 \mathrm{U}$ bend specimens suffered transgranular SCC when they were exposed for $336 \mathrm{~h}$ to aqueous solutions of $20 \% \mathrm{HF}$ at $93^{\circ} \mathrm{C}$ and to its corresponding vapor phase ${ }^{7}$ (Table 1). The liquid phase was more aggressive than the vapor phase. ${ }^{7}$ Pulvirenti et al. reported transgranular cracking in one out of four Alloy 22 U-bend specimen exposed for 15 days at $250^{\circ} \mathrm{C}$ in concentrated ground water contaminated with $0.5 \%$ lead $(\mathrm{Pb})$ and acidified to $\mathrm{pH} 0.5^{8-9}$ (Table 1). Estill et al. performed slow strain rate tests, cyclic loading tests and U-bend tests in large variety of environments (temperature, applied potential and solution composition). ${ }^{5}$ They only reported SCC on MA Alloy 22 through SSRT in saturated concentrated water $(\mathrm{SCW})$ at $73^{\circ} \mathrm{C}$ and at a potential of $+0.4 \mathrm{~V}$ [SSC] ${ }^{5}$

\section{EXPERIMENTAL TECHNIQUE}

The material for the specimen was prepared from plate stock, Heat 2277-8-3126

The chemical composition of the alloy in weight percent was: $\sim 57 \% \mathrm{Ni}, 21.7 \% \mathrm{Cr}, 13.26 \% \mathrm{Mo}$, $2.8 \% \mathrm{~W}, 3.59 \% \mathrm{Fe}, 1.03 \% \mathrm{Co}, 0.27 \% \mathrm{Mn}, 0.14 \% \mathrm{~V}, 0.004 \% \mathrm{C}$ and $0.001 \% \mathrm{~S}$

The typical mechanical properties of MA plate material are listed in Table 2.

Each specimen was cylindrical, approximately 7.25 -inch $(184 \mathrm{~mm})$ long and 0.438 -inch $(11 \mathrm{~mm})$ diameter. The useful gage of the specimens was 1-inch $(25.4 \mathrm{~mm})$ long and had a 0.1 -inch $(2.54$ $\mathrm{mm}$ ) diameter. The slow strain rate tests were conducted at a constant deformation rate of $1.6 \times 10^{-6}$ $\mathrm{s}^{-1}$. The concentration of some testing solutions are given in Table 3. The apparatus set up is shown in Figure 2.

\section{EXPERIMENTAL RESULTS AND DISCUSSION}

Table 4 shows the experimental results in SCW. Two specimens were strained to rupture in air as reference tests for inert environments. Table 4 shows the testing conditions such as testing temperature, applied potential and $\mathrm{E}_{\text {cor }}$ of the specimens in the solution before the tests. The average $\mathrm{E}_{\text {cor }}$ of all the specimens (Table 4) before starting the applied potential was approximately $-0.15 \mathrm{~V}$ in the saturated silver chloride scale [SSC] which at room temperature is approximately $200 \mathrm{mV}$ more positive than the normal hydrogen electrode [NHE].

Figure 3 shows the time to failure of the strained specimens as a function of the applied potential. Figure 3 shows that the higher the applied potential the lower the time to failure. The lowest time to failure was obtained for the specimens strained at $+0.4 \mathrm{~V}$ [SSC]. Figure 4 is an SEM image of the fracture end of a specimen strained in air. This shows typical ductile failure with necking before cracking. Figure 5 shows a SEM low magnification image of a specimen strained in SCW at $+0.1 \mathrm{~V}$ [SSC] and Figure 6 is a larger magnification of the lateral surface of the same specimen. Alloy 22 was not susceptible to cracking at $+0.1 \mathrm{~V}$ [SSC] since the specimen showed considerable necking before failure (Figure 5) and the lateral surface was free of secondary cracking (Figure 6). Figures 78 show the characteristics of a specimen strained in SCW at $+0.2 \mathrm{~V}$ [SSC]. Figure 7 shows considerable necking before failure; however, Figure 8 shows incipient secondary cracking in the lateral surface. Figure 9 is a low magnification SEM image of a specimen strained in SCW at $+0.4 \mathrm{~V}$ [SSC] showing that the failure of this specimen occurred with little reduction in area (necking). Figure 9 also shows that there is abundant secondary cracking in the lateral surface. Figure 10 is an SEM image of the fracture surface showing that the environmentally induced cracking was transgranular in nature. Figure 11 is a metallographic cross section of the same specimen showing that 
the EAC cracks are shallow and open, probably because the strain rate was high; not allowing enough time for crack propagation.

Figure 12 shows the stress-elongation curves for Alloy 22 specimens strained at $0.4 \mathrm{~V}$ in three different electrolyte solutions. Figure 12 shows that Alloy 22 was susceptible to EAC in SCW solution at $73^{\circ} \mathrm{C}$ but was not susceptible to EAC in basic saturated water (BSW) pH 12 at $105^{\circ} \mathrm{C}$ or simulated saturated water (SSW) pH 6.7 at $100^{\circ} \mathrm{C}$. Table 4 shows that when Alloy 22 was strained in $\mathrm{SCW}$ at $+0.4 \mathrm{~V}[\mathrm{SSC}]$ at ambient temperature $\left(25^{\circ} \mathrm{C}\right)$, the parameters time to failure, ultimate tensile strength and reduction in area were similar to the same parameters for the specimens strained in air.

Figure 13 shows the polarization curve for MA Alloy 22 in SCW at $90^{\circ} \mathrm{C}$. There is an anodic peak in the potential range between +0.2 to $+0.4 \mathrm{~V}$ [SSC]. The range of potential for cracking susceptibility of Alloy 22 seems to be associated to the presence of this anodic peak.

Current results show that for MA Alloy 22 to fail by EAC in SCW solution, several conditions are required to be applied simultaneously: (1) A temperature higher than approximately $70^{\circ} \mathrm{C}$, (2) A stress level in the order of $600 \mathrm{MPa}$ (two times the level of the yield stress) and (3) Anodic potentials in the order of $+0.3 \mathrm{~V}$ [SSC]. Therefore, it is unlikely that the actual container would be susceptible to EAC even though it may enter in contact with a SCW type of solution at high temperature. Firstly, because in the design of the waste package it is predicted that the container will be fully annealed to eliminate any residual stress due to welding. Second, because data (Figure 14) shows that the $\mathrm{E}_{\text {cor }}$ of Alloy 22 after more than 5 years immersion in aerated $\mathrm{SCW}$ at $90^{\circ} \mathrm{C}$ remained below $0 \mathrm{~V}$ [SSC], that is, at least $0.3 \mathrm{~V}$ below the range of potential susceptibility. Table 2 also shows that $\mathrm{E}_{\text {corr }}$ for Alloy 22 in aerated SCW was also below $0 \mathrm{~V}$ [SSC].

\section{CONCLUSIONS}

(1) Alloy 22 is resistant to EAC or SCC in concentrated chloride solutions.

(2) Alloy 22 is resistant to EAC in most multi-ionic solutions simulating concentrated underground waters.

(3) Alloy 22 was susceptible to $\mathrm{EAC}$ in SCW at +0.3 and $+0.4 \mathrm{~V}$ [SSC] at temperatures 73 $89^{\circ} \mathrm{C}$. However, EAC did not occur at $+0.4 \mathrm{~V}$ and $25^{\circ} \mathrm{C}$.

(4) It is unlikely that Alloy 22 would suffer EAC under environmental conditions that could be encountered in Yucca Mountain since the stresses of the container will be relieved and because $\mathrm{E}_{\text {cor }}$ of the alloy is expected to be below the potential range for susceptibility.

\section{ACKNOWLEDGMENTS}


The authors want to acknowledge the contributions by Gary A. Hust, James L. Ferreira and Steve R. Gordon. This work was performed under the auspices of the U. S. Department of Energy by the University of California Lawrence Livermore National Laboratory under contract $\mathrm{N}^{\circ} \mathrm{W}-7405$-Eng48. This work is supported by the Yucca Mountain Site Characterization Project, LLNL.

\section{DISCLAIMER}

This document was prepared as an account of work sponsored by an agency of the United States Government. Neither the United States Government nor the University of California nor any of their employees, makes any warranty, express or implied, or assumes any legal liability or responsibility for the accuracy, completeness, or usefulness of any information, apparatus, product, or process disclosed, or represents that its use would not infringe privately owned rights. Reference herein to any specific commercial product, process, or service by trade name, trademark, manufacturer, or otherwise, does not necessarily constitute or imply its endorsement, recommendation, or favoring by the United States Government or the University of California. The views and opinions of authors expressed herein do not necessarily state or reflect those of the United States Government or the University of California, and shall not be used for advertising or product endorsement purposes.

\section{REFERENCES}

1 Y.-M. Pan, D. S. Dunn and G. A. Cragnolino in Environmentally Assisted Cracking: Predictive Methods for Risk Assessment and Evaluation of Materials, Equipment and Structures, ASTM STP 1401, (West Conshohocken, PA 2000), pp. 273-288.

2. D. S. Dunn and C. S. Brosia, Paper 125, Corrosion/01, NACE International, (Houston, TX 2001).

3. D. S. Dunn, Y.-M. Pan and G. A. Cragnolino, Paper 425, Corrosion/02, NACE International, (Houston, TX 2002).

4. R. B. Rebak in Environmentally Assisted Cracking: Predictive Methods for Risk Assessment and Evaluation of Materials, Equipment and Structures, ASTM STP 1401, (West Conshohocken, PA 2000), pp. 289-300.

5. J. C. Estill, K. J. King, D. V. Fix, D. G. Spurlock, G. A. Hust, S. R. Gordon, R. D. McCright, G. M. Gordon and R. B. Rebak, Paper 535, Corrosion/02, NACE International, (Houston, TX 2002).

6. P. L. Andresen, P. W. Emigh, L. M. Young and G. M. Gordon, Paper 130, Corrosion/01, NACE International, (Houston, TX 2001).

7. R. B. Rebak, J. R. Dillman, P. Crook and C. V. V. Shawber, Materials and Corrosion, 52 (2001), pp. 289-297.

8. A. L. Pulvirenti, K. M. Needham, M. A. Adel-Hadadi, C. R. Marks, J. A. Gorman and A. Barkatt, Paper JJ11.6, MRS Meeting, Boston November 26-30, 2001 (In Press).

9. A. L. Pulvirenti, K. M. Needham, M. A. Adel-Hadadi, A. Barkatt, C. R. Marks and J. A. Gorman, Paper 551, Corrosion/02, NACE International, (Houston, TX 2002).

\section{TABLE 1}


PREVIOUS WORK

\section{SUSCEPTIBILITY OF ALLOY 22 TO STRESS CORROSION CRACKING}

\begin{tabular}{|c|c|c|}
\hline Reference & Tested Conditions & SCC? \\
\hline $\begin{array}{c}\text { Dunn et al. } \\
{[1-3]}\end{array}$ & $\begin{array}{c}\text { Wedge opening loaded double cantilever beam (DCB) and compact ten- } \\
\text { sion (CT) specimens at stress intensities in the range } 32 \text { to } 47 \mathrm{MPa} \cdot \mathrm{m}^{1 / 2} \\
\text { for times as long a } 52 \text { weeks in } 14 \text { molal } \mathrm{Cl}^{-}\left(\text {as } \mathrm{MgCl}_{2}\right) \text { at } 110^{\circ} \mathrm{C} \text { and } \\
9.1 \text { molal } \mathrm{LiCl} \text { at } 95^{\circ} \mathrm{C} \text { under controlled potential. }\end{array}$ & No \\
\hline Rebak [4] & U-bend specimens exposed to $45 \% \mathrm{MgCl}_{2}$ at $154^{\circ} \mathrm{C}$ for up to 6 weeks. & No \\
\hline $\begin{array}{c}\text { Estill et al. } \\
{[5]}\end{array}$ & $\begin{array}{c}\mathrm{SSRT} \text { at a } 1.6 \times 10^{-6} \mathrm{~s}^{-1} \text { strain rate at the corrosion potential }\left(\mathrm{E}_{\text {corr }}\right) \text { in } 4 \mathrm{M} \\
\mathrm{NaCl} \text { at } 98^{\circ} \mathrm{C} \text {, saturated } \mathrm{CaCl}_{2}(>10 \mathrm{M} \mathrm{Cl}) \text { at } 120^{\circ} \mathrm{C} \text { and } 1 \% \mathrm{PbCl}_{2} \text { at } \\
95^{\circ} \mathrm{C}\end{array}$ & No \\
\hline $\begin{array}{c}\text { Estill et al. } \\
{[5]}\end{array}$ & $\begin{array}{c}\mathrm{SSRT} \text { in Multi-ionic Solutions Simulating Concentrated Underground } \\
\text { Water such as } \mathrm{BSW} \text { and } \mathrm{SSW} \text { at } 100^{\circ} \mathrm{C} \text { and }+400 \mathrm{mV}[\mathrm{SSC}]\end{array}$ & No \\
\hline $\begin{array}{c}\text { Rebak et al. } \\
{[7]}\end{array}$ & $\begin{array}{c}\text { U-bend specimens exposed for } 336 \mathrm{~h} \text { to aqueous solutions of } 20 \% \mathrm{HF} \text { at } \\
93^{\circ} \mathrm{C} \text { and to its corresponding vapor phase. }\end{array}$ & Yes \\
\hline $\begin{array}{c}\text { Pulvirenti et } \\
\text { al. [8-9] }\end{array}$ & $\begin{array}{c}\text { U-bend specimen exposed for } 15 \text { days at } 250^{\circ} \mathrm{C} \text { in concentrated ground } \\
\text { water contaminated with } 0.5 \% \text { lead }(\mathrm{Pb}) \text { and acidified to } \mathrm{pH} 0.5\end{array}$ & Yes \\
\hline & & \\
\hline
\end{tabular}

TABLE 2

TYPICAL MECHANICAL PROPERTIES OF PLATE AND SHEET ALLOY 22

\begin{tabular}{cccccc}
\hline Heat & $\begin{array}{c}\text { Tensile } \\
\text { Strength [UTS] } \\
\text { (MPa) }\end{array}$ & $\begin{array}{c}\text { Yield Stress } \\
{[0.2 \%](\mathrm{MPa})}\end{array}$ & $\begin{array}{c}\text { Elongation to } \\
\text { Rupture (\%) }\end{array}$ & $\begin{array}{c}\text { Hardness } \\
\text { (RB) }\end{array}$ & $\begin{array}{c}\text { ASTM } \\
\text { Grain } \\
\text { Size }\end{array}$ \\
\hline $\begin{array}{c}\text { Sheet - 2277- } \\
8-3203\end{array}$ & 824 & 412 & 62 & 92 & 5.5 \\
$\begin{array}{c}\text { Plate-2277-8- } \\
3126\end{array}$ & 766 & 387 & 64.4 & 83 & 4 \\
\hline
\end{tabular}

TABLE 3 
CONCENTRATION OF TYPICAL UNDERGROUND WATERS IN mg/L

\begin{tabular}{lccccc}
\hline Ion & $\begin{array}{c}\text { J-13 } \\
\text { Well Water } \\
\text { pH 7.4 }\end{array}$ & $\begin{array}{c}\text { Unsaturated } \\
\text { Zone (UZ) } \\
\text { Pore Water } \\
\text { pH 5.6 }\end{array}$ & $\begin{array}{c}\text { Simulated } \\
\text { Concentrated } \\
\text { Water (SCW) } \\
\text { pH 10.3 }\end{array}$ & $\begin{array}{c}\text { Simulated } \\
\text { Saturated } \\
\text { Water (SSW) } \\
\text { pH 6.7 }\end{array}$ & $\begin{array}{c}\text { Basic Satu- } \\
\text { rated Water } \\
\text { (BSW) } \\
\text { pH 13 }\end{array}$ \\
\hline & & & & & \\
$\mathrm{K}^{+}$ & 5.04 & 0.01 & 3400 & 141,600 & 81,480 \\
$\mathrm{Na}^{+}$ & 45.8 & 9 & 40900 & 487,000 & 231,225 \\
$\mathrm{Mg}^{2+}$ & 2.01 & 12 & $<1$ & -- & -- \\
$\mathrm{Ca}^{2+}$ & 13 & 65 & $<1$ & -- & -- \\
$\mathrm{F}^{-}$ & 2.18 & 0 & 1400 & -- & 1616 \\
$\mathrm{Cl}^{-}$ & 7.14 & 77 & 6700 & 128,000 & 169,204 \\
$\mathrm{NO}_{3}^{-}$ & 8.78 & 12 & 6400 & $1,313,000$ & 177,168 \\
$\mathrm{SO}_{4}^{2-}$ & 18.4 & 79 & 16700 & --- & 16,907 \\
$\mathrm{HCO}_{3}^{-}$ & 128.9 & 66 & 70000 & --- & 107,171 \\
$\mathrm{SiO}_{3}{ }^{2-}$ & 61.1 & 46 & $\sim 40$ & -- & 9038 \\
& & & & & \\
\hline
\end{tabular}

TABLE 4

SLOW STRAIN RATE $\left(\sim 1.6 \times 10^{-6} \mathrm{~S}^{-1}\right)$ TESTING OF MA ALLOY $22 \mathrm{IN}$ SCW

\begin{tabular}{|c|c|c|c|c|c|c|c|}
\hline Sample & $\begin{array}{l}\text { Temp. } \\
\left({ }^{\circ} \mathrm{C}\right)\end{array}$ & $\begin{array}{l}\mathrm{E}_{\text {corr }} \\
(\mathrm{mV}, \\
\mathrm{SSC})\end{array}$ & $\begin{array}{l}\mathrm{E}_{\text {applied }} \\
(\mathrm{mV} \text {, } \\
\mathrm{SSC} \text { ) }\end{array}$ & $\begin{array}{c}\text { Time to } \\
\text { Failure }(\mathrm{h})\end{array}$ & $\begin{array}{l}\text { UTS } \\
\text { (ksi) }\end{array}$ & $\begin{array}{l}\text { RA } \\
(\%)\end{array}$ & $\begin{array}{c}\text { Observations } \\
\text { Stereomicroscope } \\
\text { X } 40 \text { and X100 }\end{array}$ \\
\hline 012 (Air) & 22 & NA & $\overline{\mathrm{NA}}$ & 124 & 114 & 74 & Ductile, Necking \\
\hline 040 (Air) & 22 & NA & NA & 123 & 118 & 70 & Ductile, Necking \\
\hline 026 & 73 & -241 & +100 & 120 & 111 & 79 & $\begin{array}{l}\text { Ductile Failure, neck- } \\
\text { ing. No SCC }\end{array}$ \\
\hline 023 & 73 & -224 & +200 & NA & NA & 72 & $\begin{array}{l}\text { Necking. Incipient or } \\
\text { Shallow SCC }\end{array}$ \\
\hline 025 & 73 & -172 & +200 & 116 & NA & 80 & $\begin{array}{l}\text { Necking. Incipient or } \\
\text { Shallow SCC }\end{array}$ \\
\hline 029 & 88.5 & -144 & +200 & 112 & NA & 73 & $\begin{array}{l}\text { Necking. Incipient or } \\
\text { Shallow SCC }\end{array}$ \\
\hline 030 & 73 & -182 & +300 & 98 & NA & 65 & $\mathrm{SCC}$ \\
\hline 021 & 73 & -171 & +400 & 90 & 96 & 64 & $\mathrm{SCC}$ \\
\hline 112 & 95 & -94 & +400 & 91 & 101 & 71 & $\mathrm{SCC}$ \\
\hline 033 & 86 & -169 & +400 & 76 & NA & 44 & $\mathrm{SCC}$ \\
\hline 020 & 25 & -109 & +400 & 116 & 114 & 85 & $\begin{array}{l}\text { Ductile Failure, neck- } \\
\text { ing. No SCC }\end{array}$ \\
\hline
\end{tabular}

RA: Reduction in area at time of rupture, NA $=$ Not Applicable or Not Available. For many samples the UTS value was not recorded during testing, that is, the data is not available. 


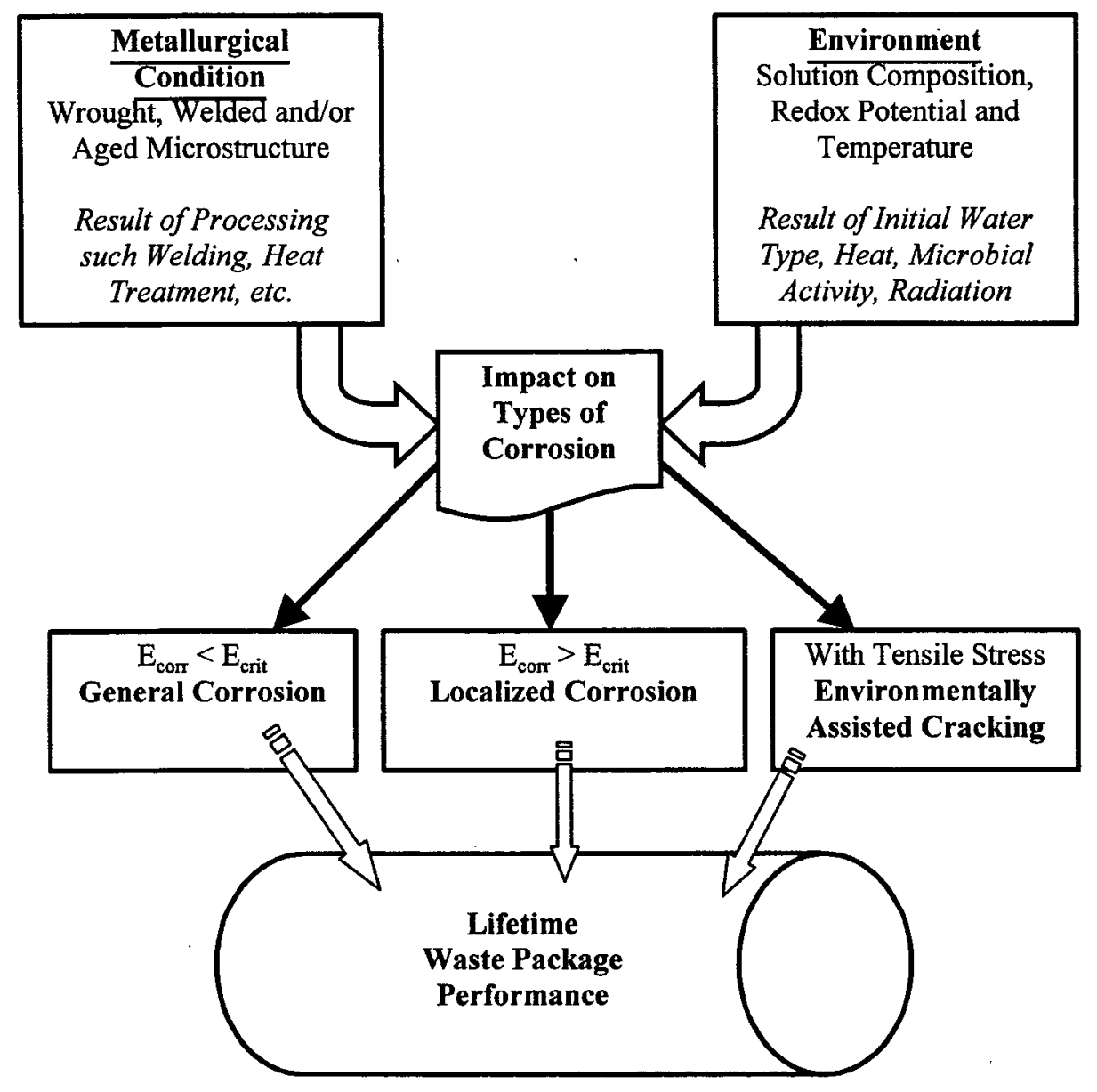

FIGURE 1: General Model For Corrosion Degradation of Alloy 22 


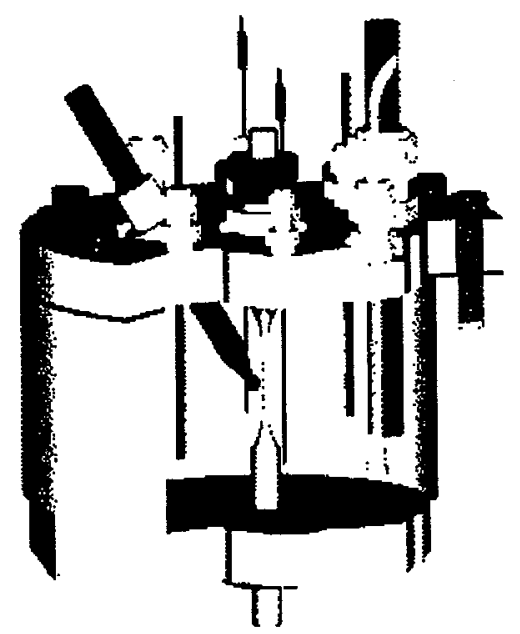

Figure 2: Apparatus Set Up for SSRT Testing

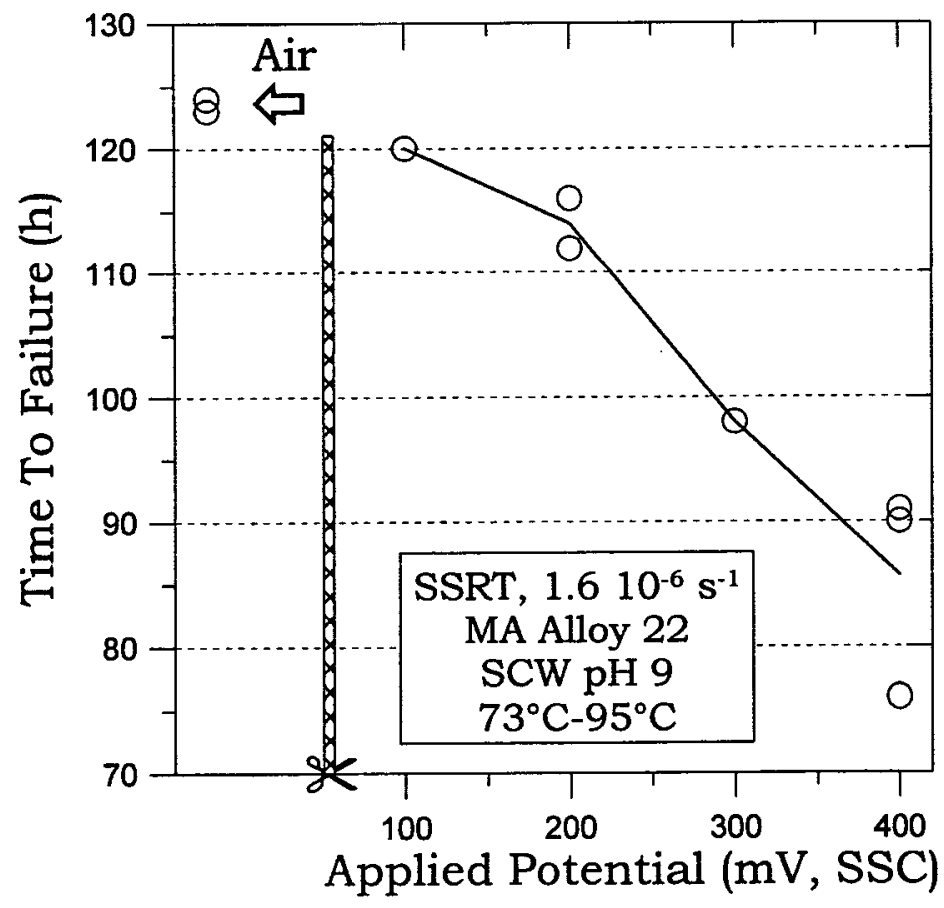

FIGURE 3: Effect of Potential on the time to failure of Alloy 22 in SCW. 


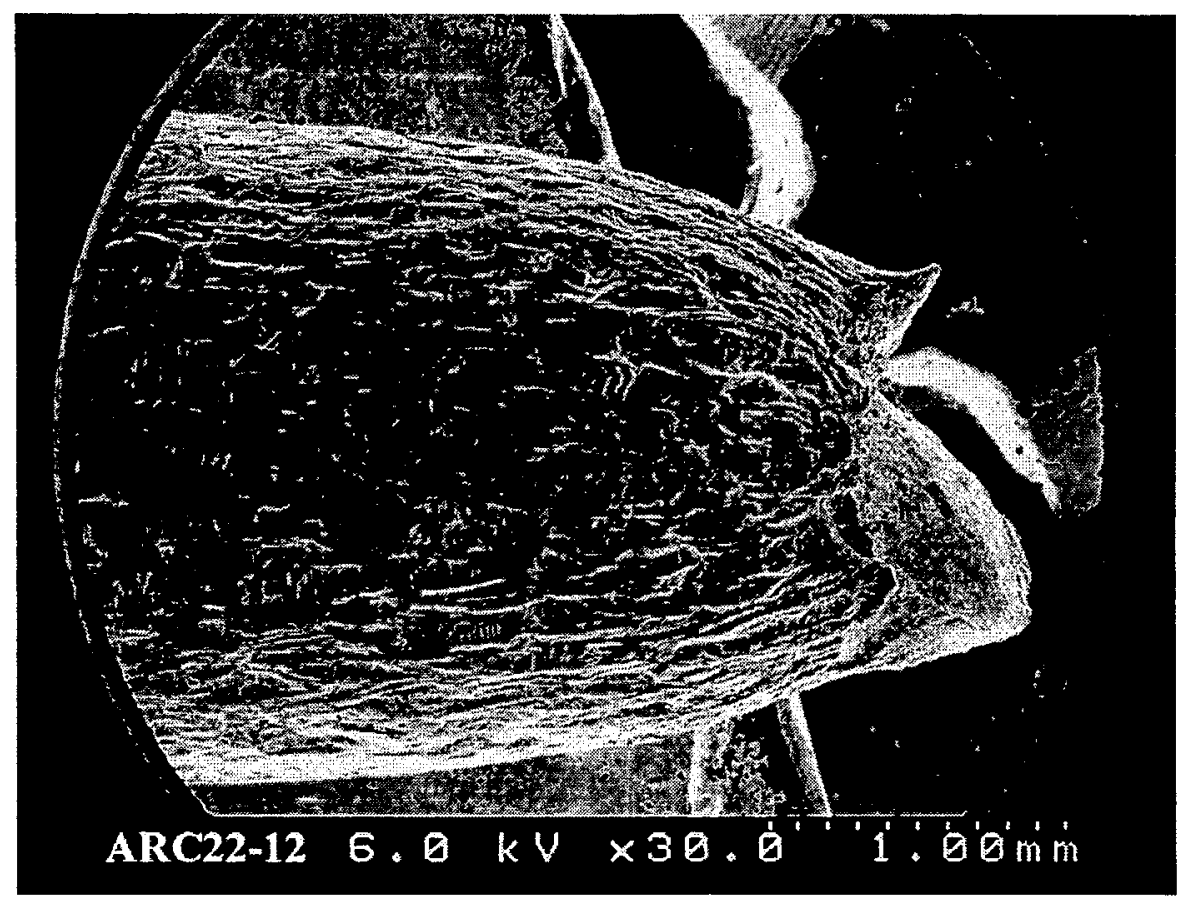

FIGURE 4: Fracture end of specimen strained in air at ambient temperature. Magnification X 30 .

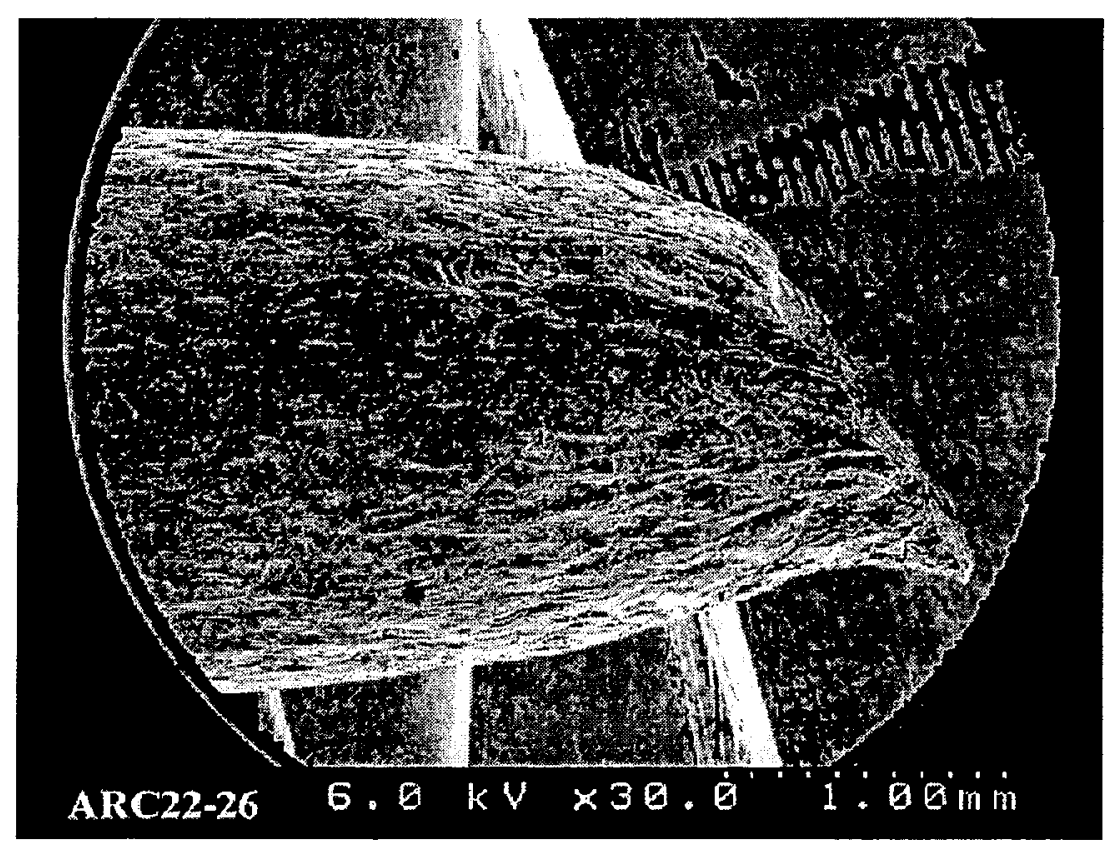

FIGURE 5: Fracture end of specimen strained in $\mathrm{SCW}$ at $73^{\circ} \mathrm{C}$ and $+0.1 \mathrm{~V}$. Magnification X 30. 


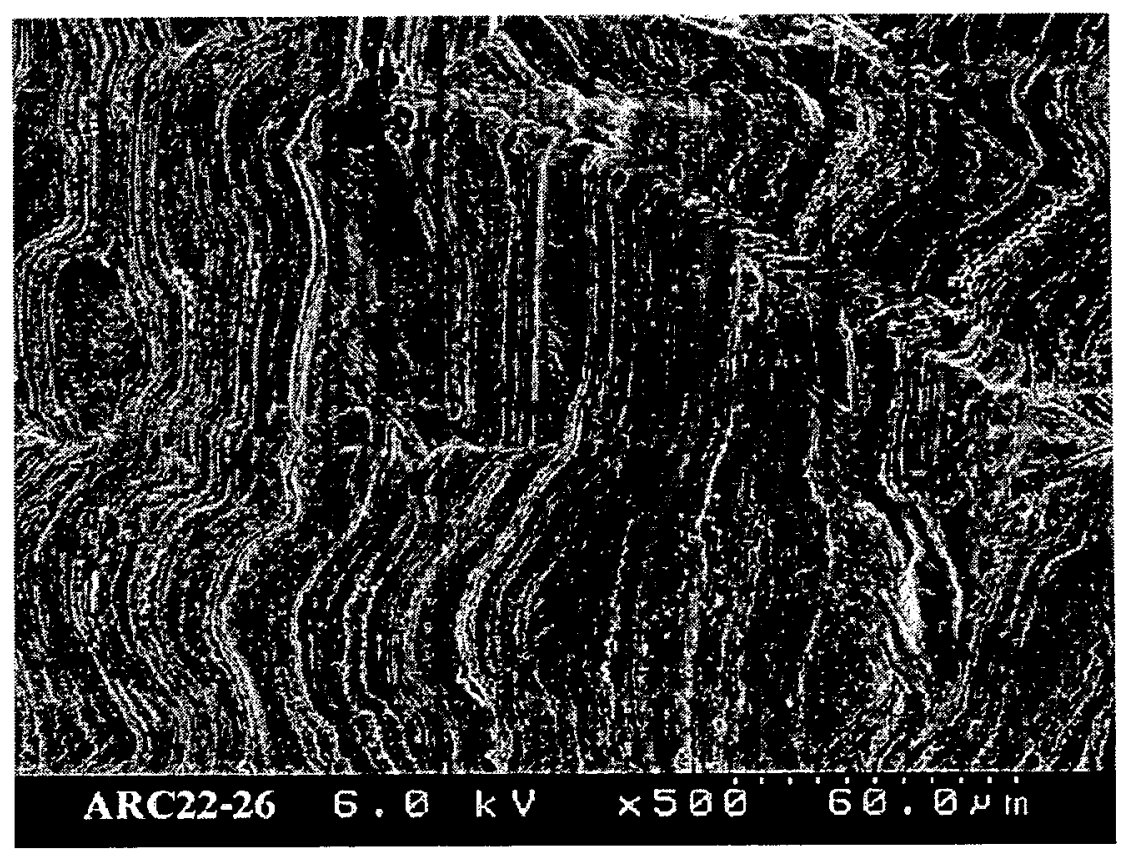

FIGURE 6: Fracture end of specimen strained in SCW at $73^{\circ} \mathrm{C}$ and $+0.1 \mathrm{~V}$. Magnification X 500.

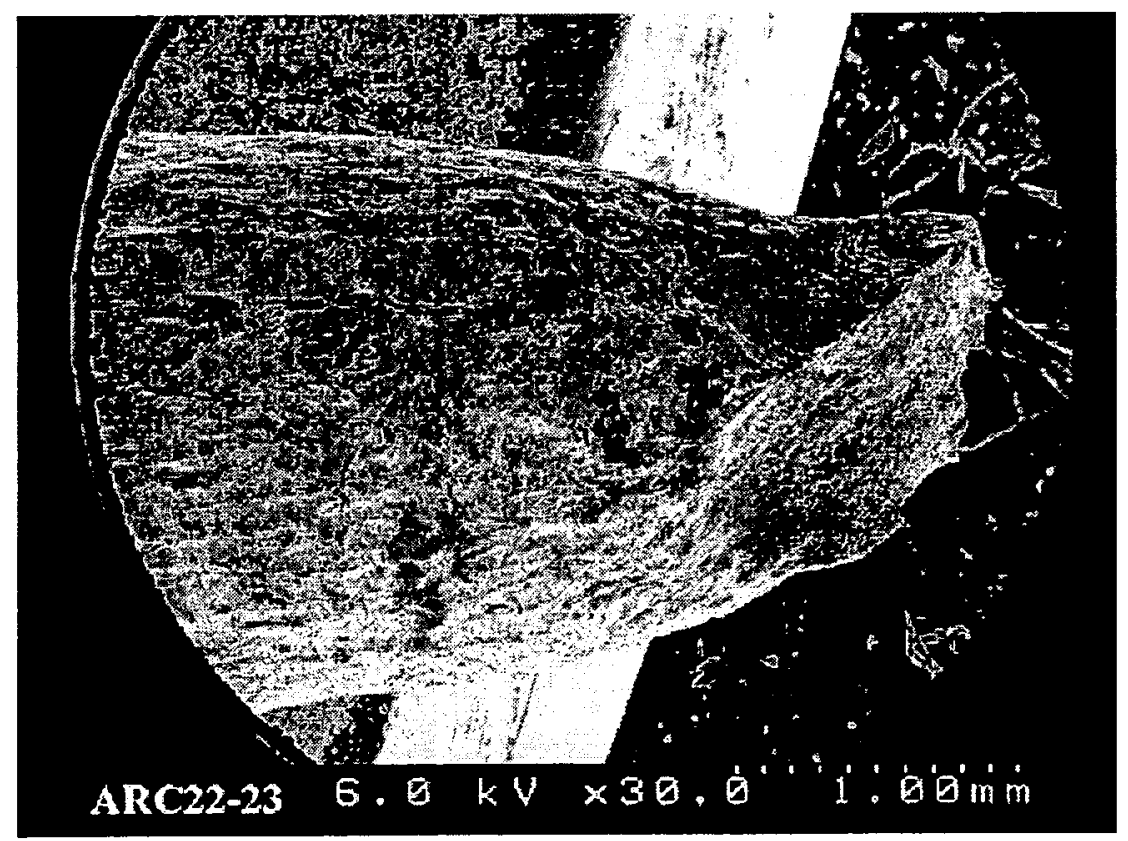

FIGURE 7: Fracture end of specimen strained in SCW at $73^{\circ} \mathrm{C}$ and $+0.2 \mathrm{~V}$. Magnification X 30. 


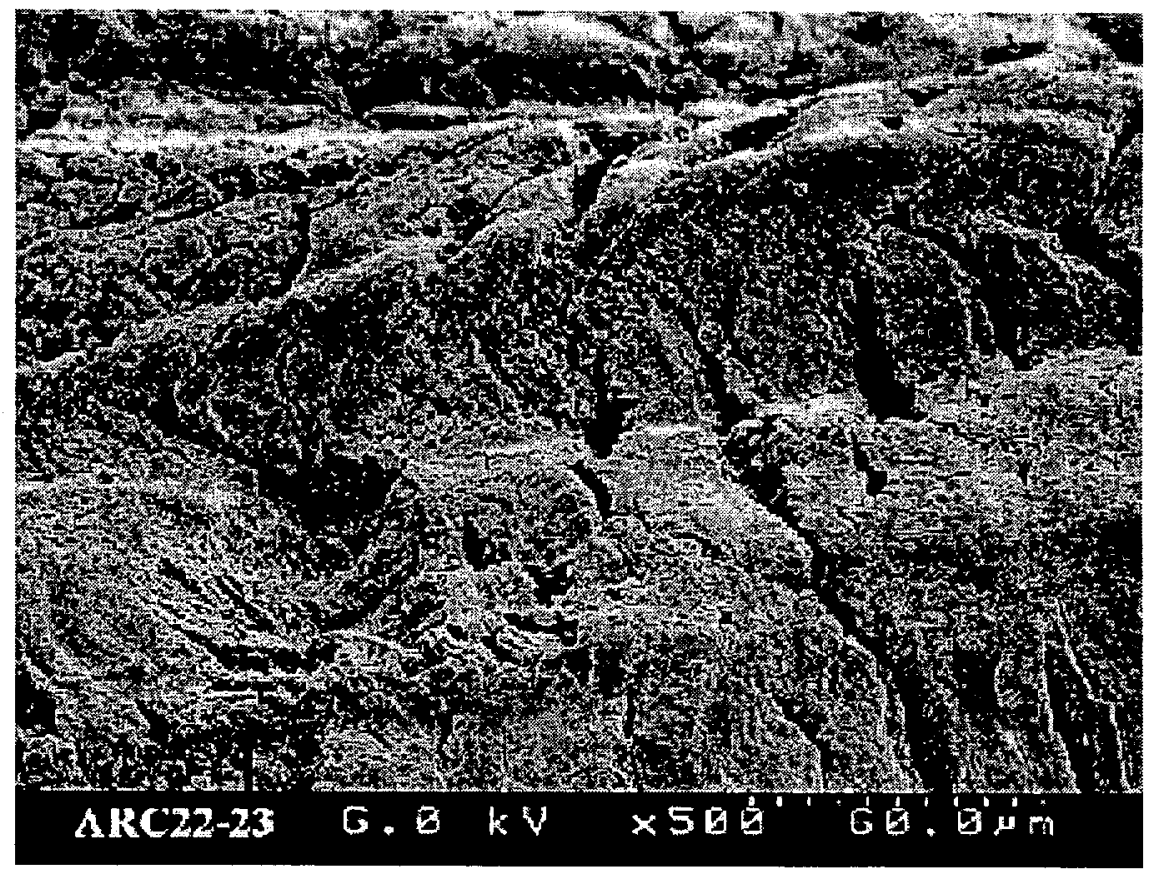

FIGURE 8: Fracture end of specimen strained in $\mathrm{SCW}$ at $73^{\circ} \mathrm{C}$ and $+0.2 \mathrm{~V}$. Magnification X 500.

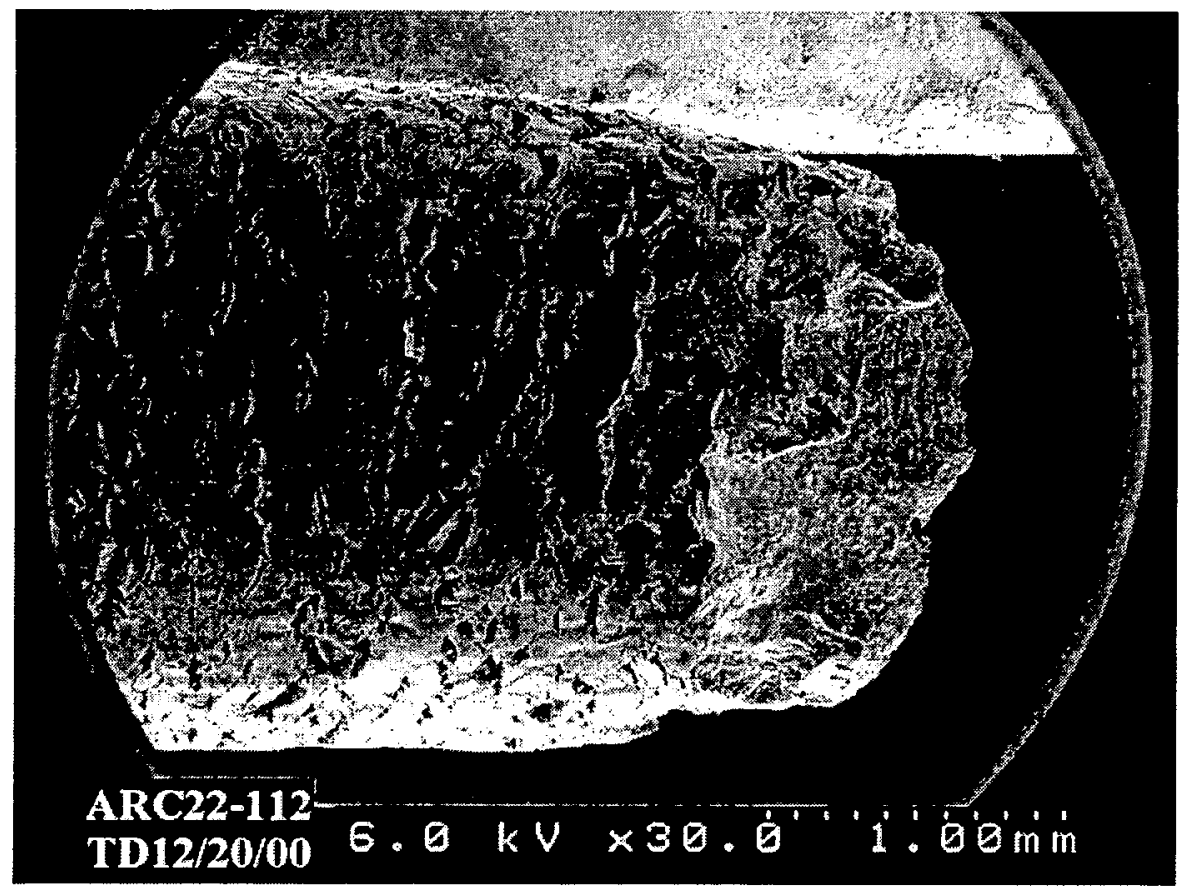

FIGURE 9: Fracture end of specimen strained in SCW at $73^{\circ} \mathrm{C}$ and $+0.4 \mathrm{~V}$. Magnification X 30 . 


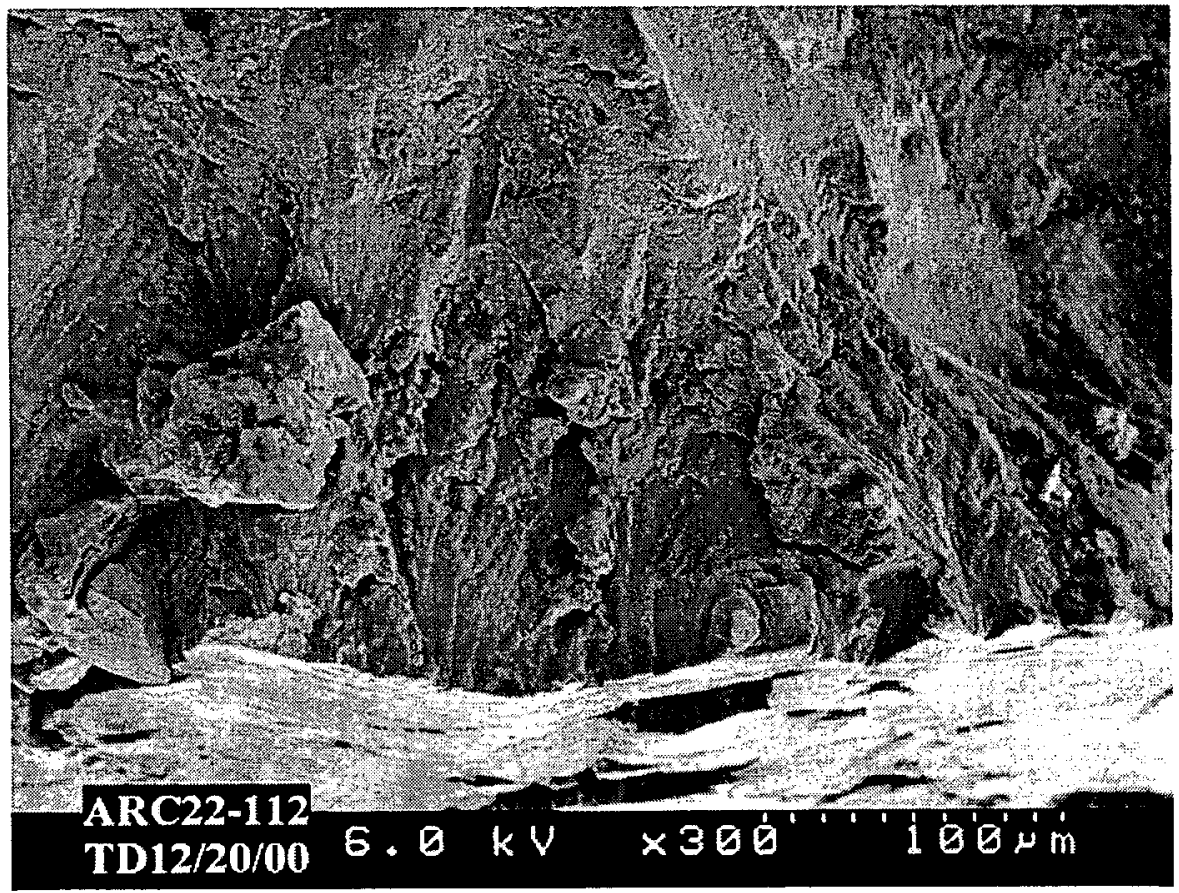

FIGURE 10: Fracture surface of specimen strained in SCW at $73^{\circ} \mathrm{C}$ and $+0.4 \mathrm{~V}$. Magnification X 300.

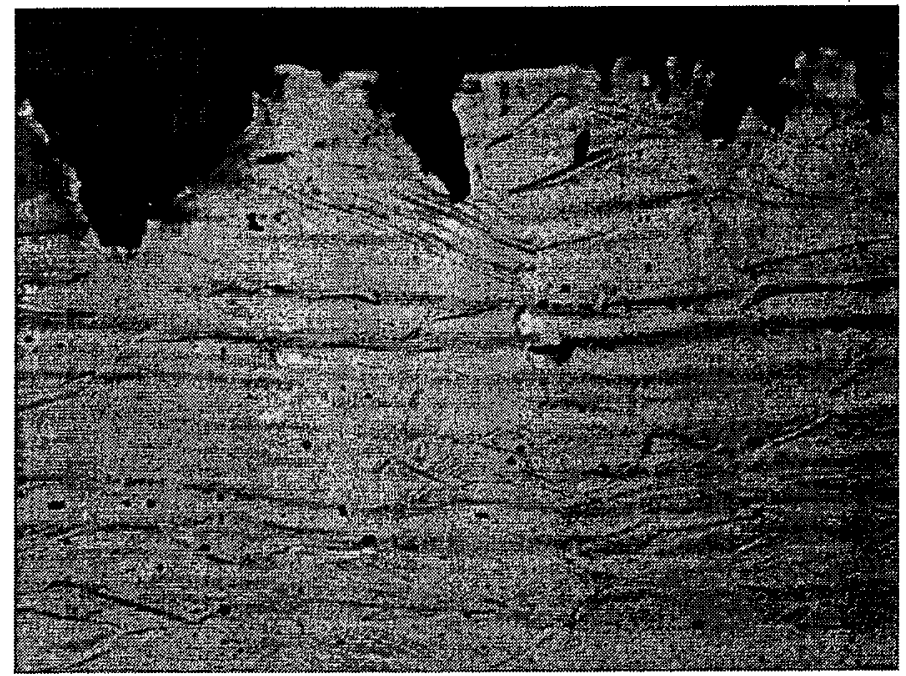

FIGURE 11: Metallographic sectioning of Alloy 22 (112) strained in SCW at $73^{\circ} \mathrm{C}$ and $+0.4 \mathrm{~V}$. Magnification X 200. 


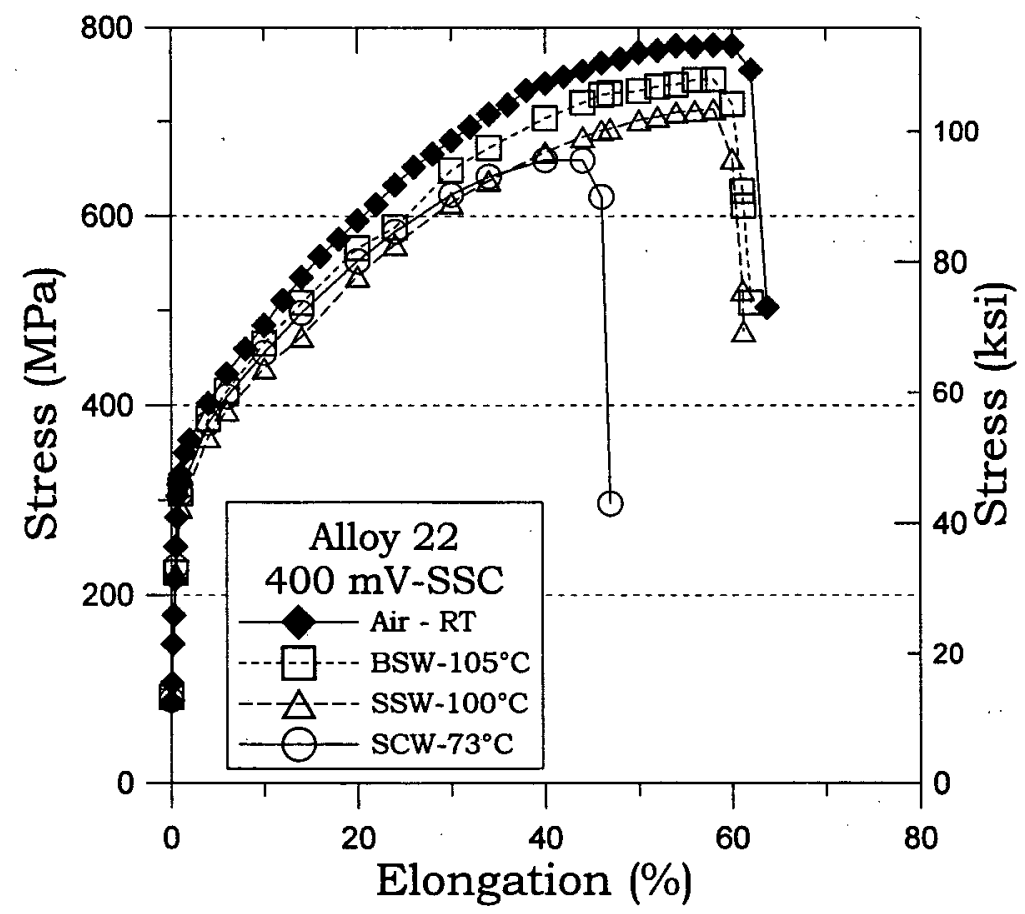

FIGURE 12: Stress-Elongation curves for Alloy 22 specimens strained at $+0.4 \mathrm{~V}$.

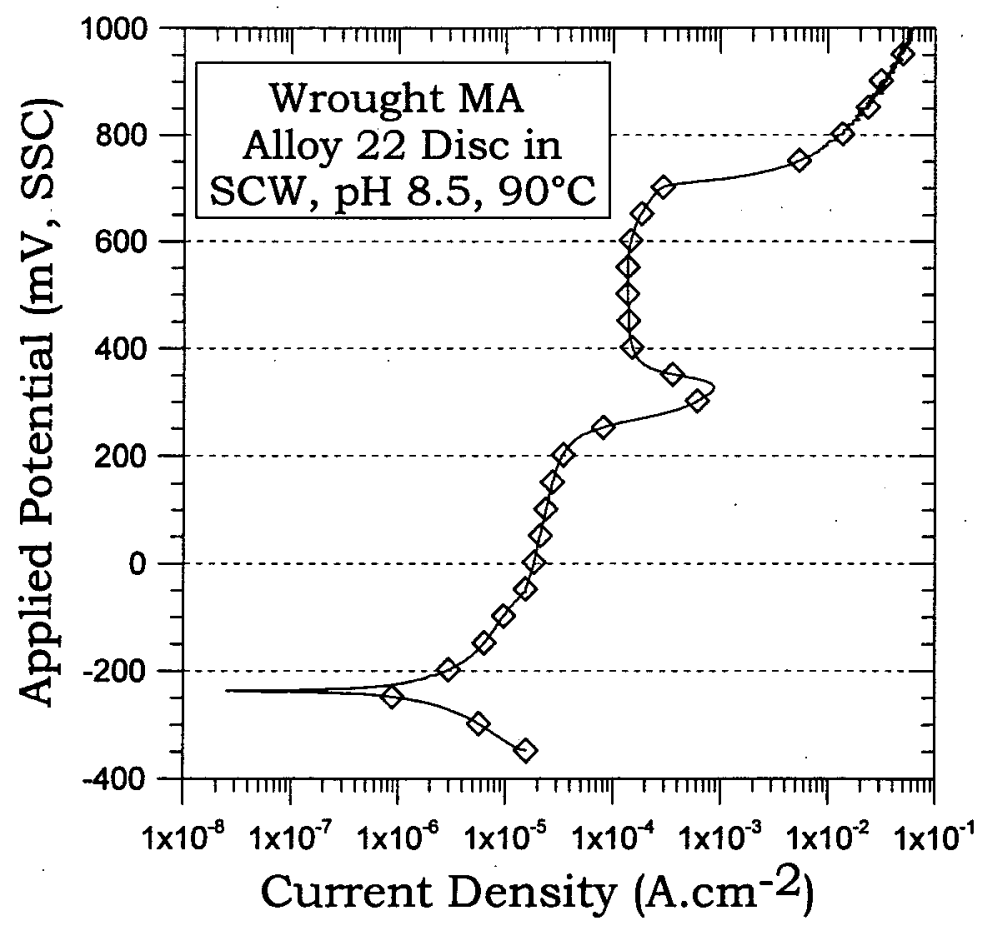

FIGURE 13: Polarization Curve for MA Alloy 22 in SCW at $90^{\circ} \mathrm{C}$. 


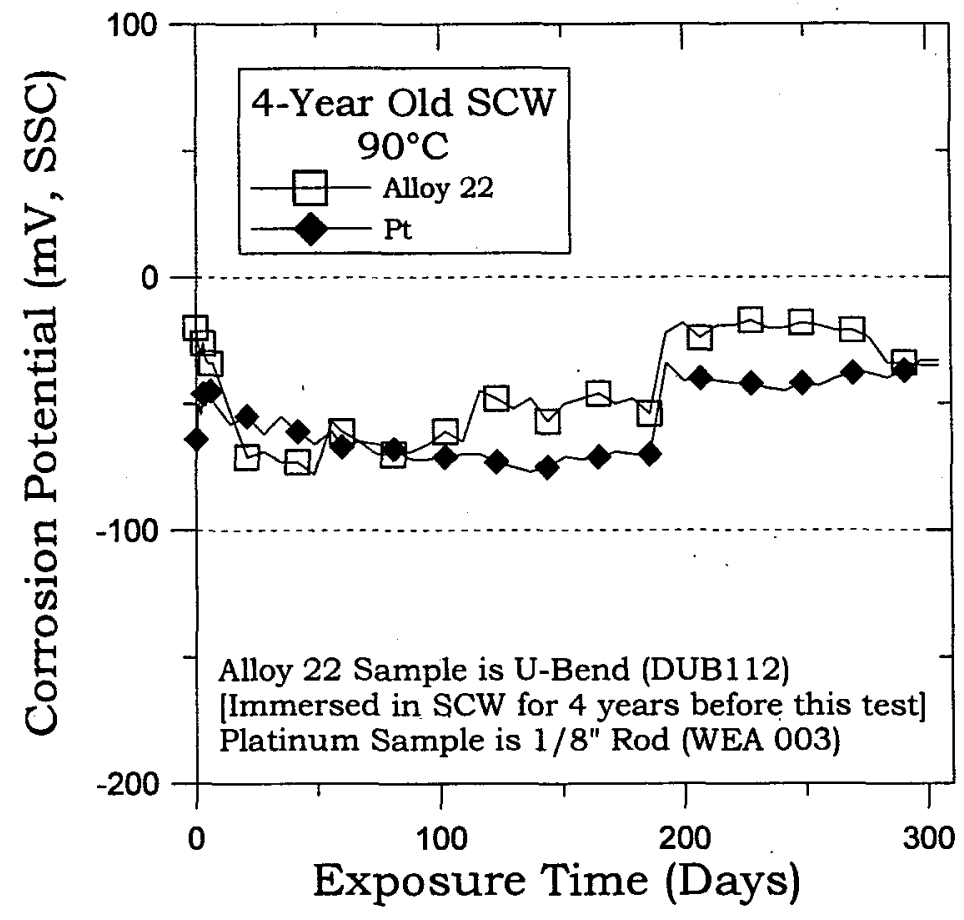

FIGURE 14: Corrosion Potential of Alloy 22 and Platinum in 4-year old SCW solution (from the Long Term Corrosion Test Facility). 